\title{
ASPEK YURIDIS DALAM PERJANJIAN MUSYARAKAH PADA BANK MUAMALAT INDONESIA \\ Oleh: Mundorin
}

Program Magister Ilmu Hukum

Pascasarjana Fakultas Hukum Universitas Islam Malang

Jalan Mayjen Haryono No. 139 Malang

\begin{abstract}
Abstrak
Untuk menjamin terlaksanannya akad Pembiayaan Musyarakah pada Bank Muamalat Indonesia Cabang Banyuwangi, maka dilakukan sebuah kontrak/perjanjian antara bank dan nasabah. Kontrak tersebut dijadikan payung hukum dalam pelaksanaan akad yang memberikan gambaran suatu komitmen pihak, masing-masing wajib mentaati apa yang telah dituangkan dalam kontrak (akad) Perjanjian pembiayaan Musyarakah ini berdasar atas peraturan perundang-undangan perbankan syari'ah, terutama Undang-Undang Nomor 21 tahun 2008 tentang perbankan Syari'ah, sehingga dapat disimpulkan lebih detail lagi bahwa pelaksanaan pembiayaan Musyarakah pada bank Muamalat Indonesia cabang Banyuwangi dilaksanakan bersarkan Hukum Islam dan Hukum Fositif.

Kata Kunci: bank, perjanjian, yuridis, Islam
\end{abstract}

\section{Abstract}

To guarantee the implementation of the Musyarakah Financing contract at Bank Muamalat Indonesia Banyuwangi Branch, a contract / agreement is held between the bank and the customer. The contract is used as a legal umbrella in the implementation of the contract that gives a description of a party's commitment, each must obey what has been stated in the contract (contract). in 2008 concerning Syari'ah banking, so that it can be concluded in more detail that the implementation of Musyarakah financing at the Muamalat Indonesia bank in the Banyuwangi branch was carried out based on Islamic Law and Phositive Law.

Keywords: bank, agreement, juridical, Islam

\section{PENDAHULUAN}

Kehidupan modern sekarang ini untuk memenuhi berbagai kebutuhan hidup yang semakin banyak dan kompleks, sedangkan kemampuan untuk memenuhi kebutuhan tersebut sangat terbatas, sehingga jasa pelayanan perbankan adalah sebagai alternatif untuk mengatasi keterbatasan tersebut. Hampir setiap orang memerlukan jasa layanan bank, baik sebagai upaya untuk memperoleh dana dari 
bank, tambahan dana atas jasa tabungan maupun untuk pengamanan dana yang ada.

Di Indonesia pada saat ini dikenal dengan dua sistem perbankan yaitu sistem perbankan konvensional dan perbankan syariah sebagaimana telah diatur dalam Undang-Undang Nomor 10 Tahun 1998 tentang Perubahan Undang-Undang Nomor 7 Tahun 1992 tentang Perbankan. Menurut Pasal 1 Undang-Undang Nomor 7 Tahun 1992 tentang Perbankan, dikenal ada dua bentuk bank, yaitu 1) Bank Umum, dan 2) Bank Perkreditan Rakyat. Selanjutnya dalam Pasal 1 angka 3 undang-undang tersebut, diartikan, bahwa Bank Umum adalah bank yang melaksanakan kegiatan usaha secara konvensional dan/atau berdasarkan prinsip syariah yang dalam kegiatannya memberikan jasa dalam lalu lintas pembayaran. ${ }^{1}$ Sedangkan Bank Perkreditan adalah bank yang melaksanakan kegiatan usaha secara konvensional atau berdasarkan Prinsip Syariah yang dalam kegiatannya tidak memberikan jasa dalam lalu lintas pembayaran. ${ }^{2}$

Sistem bank konvesional dengan menerapkan sistem bunga (interest fee), sementara bagi masyarakat muslim Indonesia keberadaan bank dengan sistem bunga masih menjadi perdebatan tentang kebolehannya ditinjau dari syariat Islam. Sebagian masyarakat beranggapan bahwa bunga tidak termasuk dalam kategori riba yang diharamkan karena keadaan yang memaksa harus demikian (darurat), namun sebagian lagi beranggapan bahwa bunga adalah termasuk riba yang diharamkan oleh Allah sebagaimana firman Allah dalam surah al-Baqarah (2) ayat 275:

Artinya : ... Dan Allah telah menghalalkan jual beli dan mengharamkan riba... (QS.2 : 275).

Dan firman Allah dalam surah Ali Imran (3) ayat 130 :

Artinya : Hai orang-orang yang beriman, janganlah kamu memakan Riba dengan berlipat ganda dan bertakwalah kamu kepada Allah supaya kamu mendapat keberuntungan. (QS. 3 : 130)

Berkenaan dengan masalah riba maka peranan cendekiawan Muslim sangat dituntut untuk menggali konsepsi dasar tentang sistem perbankan yang sesuai dengan prinsip-prinsip syariah Islam. ${ }^{3}$ Setelah melalui berbagai pengkajian sehingga pada tahun 1992 didirikanlah Bank Mualamat Indonesia (BMI) sebagai bank yang beroperasi berlandaskan pada prinsip-prinsip syariah dengan visinya "Menjadi bank syariah utama di Indonesia dominan di pasar spiritual, dikagumi di pasar nasional."

Pada saat ini Perbankan Syari'ah (Islam) berkembang cukup pesat yang dibuktikan dengan semakin banyaknya hadir dan beroperasinya lembaga Keuangan Syari'ah (LKS) dan Bisnis Syari'ah bahkan Bank Konvensional juga telah banyak yang membuka Unit Usaha perbankan Syari'ah, baik Bank milik pemerintah maupun swasta, baik bank milik Pemerintah Pusat maupun Pemerintah

\footnotetext{
${ }^{1}$ Redaksi Sinar Grafika, Undang-Undang Perbankan, (Jakarta: Sinar Grafika), hal. 9

2 Ibid. hal. 9

${ }^{3}$ Warkum Sumitro, Asas-Asas Perbankan Islam dan Lembaga-Lembaga Terkait, Edisi Revisi, Raja Grafindo Persada, Jakarta, 1996, hal. 8
} 
Daerah, baik Bank Nasional maupun Bank asing, seperti halnya BRI Syariah, BNI Syariah, Bank Mandiri Syariah, Bank Danamon Syariah, BCA Syariah, BII Syariah, Bank DKI Syariah, Bank Kalbar Syariah, HSBC Syariah dan lain sebagainya.

Dengan bermunculannya Lembaga Keuangan Syari'ah maka perlu mendapatkan perhatian serius dari para praktisi Hukum terutama praktisi Hukum Islam terhadap kemurnian pelaksanaan sistem ekonomi Syari'ah.

Perbankan Islam yang merupakan aplikasi dari sebuah sistem perekonomian, salah satu sistem yang sedang berkembang adalah sistem musyarakah. Perkembangan bank Islam semakin menunjukkan angka yang membahagiakan, baik ditanah air maupun di manca negara, perbankan Islam seringkali disebut sebagai bank bagi hasil. Hal ini dilakukan untuk memberikan perbedaan definisi antara bank Islam dengan bank konvensional yang sangat akrab dengan operasional sistem bunga ${ }^{4}$.

Dengan menggunakan prinsip Syari'ah, maka Bank Syari'ah harus berpedoman kepada ketentuan-ketentuan Syari'ah atau Hukum Islam. Setiap kegiatan usaha yang dilakukan harus mempertimbangkan halal haramnya menurut Hukum Islam. Prinsip Syariah, sebagaimana disebutkan dalam Pasal 1 angka 13 UndangUndang Nomor : 10 Tahun 1998 adalah :

Aturan perjanjian berdasarkan hukum Islam antara bank dan pihak lain untuk penyimpanan dan/atau pembiayaan kegiatan usaha, atau kegiatan lainnya yang dinyatakan sesuai dengan Syari'ah, antara lain, pembiayaan berdasarkan prinsip bagi hasil (mudharabah), pembiayaan berdasarkan prinsip penyertaan modal (musyarakah), prinsip jual beli barang dengan memperoleh keuntungan (murabahah), atau pembiayaan barang modal berdasarkan prinsip sewa murni tanpa pilihan (ijarah), atau dengan adanya pilihan pemindahan kepemilikan atas barang yang disewa dari pihak bank oleh pihak lain (ijarah wa ishtisna). ${ }^{5}$

Salah satu prinsip yang harus dilaksanakan oleh bank yang menganut prinsip syariah adalah bagi hasil (profit sharing). Menurut Syafi'i Antonio penerapan prinsip syariah dapat dilakukan dalam empat akad utama, yaitu : al-musyarakah, almudharabah, al-muzara'ah dan al-musaqah. ${ }^{6}$

Al-Muzara'ah adalah kerjasama dalam bidang pertanian dan perkebunan antara pemilik lahan dengan petani. Al-Muzara'ah terbagi dua, yaitu :

a. Muzara'ah : kerjasama pengolahan dimana benih-benih berasal daripemilik lahan.

${ }^{4}$ Adiwarman A. Karim, Bank Islam : Analisis Fiqih dan Keuangan, (Jakarta: PT. Raja Grafindo Persada, 2008), hal. 203

${ }^{5}$ Redaksi Sinar Grafika, Op. It, hal.7.

${ }^{6}$ Muhammad Syafi'i Antonio, Bank Syari'ah Dari Teori ke Praktek, (Jakarta: Gema Insani Press, 2001), hal. 90. 
b. Mukhabarah : kerjasama pengolahan lahan di mana benih berasal dari penggarap. ${ }^{7}$

Al-Musaqah adalah bentuk sederhana dari dari Muzara'ah, dimana si penggarap hanya bertanggung jawab atas penyiraman dan pemeliharaan. Sebagai imbalan si penggarap berhak atas bagian tertentu dari hasil panen. ${ }^{8}$

Diantara keempat akad utama tersebut, prinsip yang paling banyak dipakai adalah al-musyarakah dan al-mudharabah, sedangkan al-muzara'ah dan al-musaqah dipergunakan khusus untuk plantation financing atau pembiayaan pertanian oleh beberapa bank Islam. ${ }^{9}$

Bank umum yang menggunakan prinsip syariah dalam kegiatan operasionalnya sama halnya dengan bank konvensional yaitu selain melakukan kegiatan penghimpunan dana juga menyalurkan dana kepada masyarakat.

Kegiatan usaha bank umum berdasarkan prinsip syariah diatur dalam Surat Keputusan Direksi Bank Indonesia Nomor : 31/34/KEP/DIR tentang Bank Umum Berdasarkan Prinsip Syariah tanggal 12 Mei 1999. Dalam Pasal 38 Surat Keputusan tersebut disebutkan, bahwa :

Bank wajib menerapkan Prinsip Syariah dalam melakukan kegiatan usahanya, meliputi :

a. menghimpun dana dari masyarakat dalam bentuk simpanan yang meliputi :

1. giro berdasarkan prinsip wadi'ah;

2. tabungan berdasarkan prinsip wadi'ah atau mudharabah;

3. deposito berjangka berdasarkan prinsip syariah mudharabah; atau

4. bentuk lain berdasarkan prinsip wadi'ah atau mudharabah.

b. melakukan penyaluran dana melalui :

1. transaksi jual beli berdasarkan prinsip :

a) murabahah;

b) istishna;

c) ijarah;

d) salam;

e) jual beli lainnya.

2. pembiayaan bagi hasil berdasarkan prinsip :

a) mudharabah;

b) musyarakah;

c) bagi hasil lainnya.

3. pembiayaan lainnya berdasarkan prinsip:

a) hiwalah;

b) rahn;

${ }^{7}$ Habib Nazir, et. all, Ensiklopedi Ekonomi \& Perbankan Syariah, (Bandung: Kafa Publishing, Cetakan II, 2008), hal. 473

${ }^{8}$ Ibid, hal. 465

${ }^{9}$ Muhammad Syafi' i Antonio,Op. Cit., hal.90 
c) qardh. $^{10}$

Untuk menghindari kekeliruan dalam memahami beberapa peristilahan yang dipergunakan dalam perbankan syari'ah, penulis akan mengemukakan beberapa pengertian dari istilah-istilah tersebut, sebagai berikut :

Mudharabah (Trust Financing, Trust Invesment), disebut juga Muqaradhah, berarti bepergian untuk urusan dagang. Dalam kontek fikih mudharabah berarti pemilik modal (shahibul maal) menyerahkan modalnya kepada pekerja/pedagang (mudharib) untuk diusahakan. Sedangkan keuntungannya dibagi menurut kesepakatan bersama. ${ }^{11}$

Wadi'ah (Trustee Depository) berasal dari kata wada'a yang berarti meninggalkan atau berpisah, atau sesuatu yang diletakkan pada yang bukan miliknya untuk dijaga. Dalam bahasa Indonesia wadi'ah diterjemahkan dengan "titipan". ${ }^{12}$

Murabahah (Defered Payment Sale), menurut definisi Ulama Fiqh adalah akad jual beli atas barang tertentu. Dalam transaksi penjualan tersebut penjual menyebutkan secara jelas barang yang akan dibeli termasuk harga pembelian barang dan keuntungan yang akan diambil.

Istishna (Purchase by Order or Manufacture) adalah suatu transaksi jual beli antar mustashni' (pemesan) dengan shani' (produsen), dimana barang yang akan diperjualbelikan harus dipesan terlebih dahulu dengan kriteria yang jelas. ${ }^{14}$

Secara etimologi ijarah disebut juga al ajru (upah) atau al 'iwadh (ganti). Atau ijarah disebut juga upah, sewa, hasa, atau imbalan. Sedangkan menurut istilah syara' adalah merupakan salah satu bentuk kegiatan muamalah dalam memenuhi kebutuhan hidup manusia, seperti sewa menyewa dan mengontrak atau menjual jasa. Ulama fiqh mendefinisikan ijarah sebagai akad yang dilakukan atas dasar suatu manfaat dengan imbalan jasa. ${ }^{15}$

Salam (Infront of Payment Sale) secara etimologi berarti salaf (pendahuluan) yang bermakna akad atau penjualan/pembuatan sesuatu yang disepakati dengan kriteria tertentu dalam tempo (tanggungan), sedang pembayaran disegerakan. ${ }^{16}$

Hiwalah adalah pemindahan hak atau kewajiban yang dilakukan seseorang (pihak pertama) yang sudah tidak sanggup lagi untuk membayarnya kepada pihak kedua yang memiliki kemampuan untuk mengambil alih atau untuk menuntut pembayaran uang dari/atau membayar utang kepada pihak ketiga. ${ }^{17}$

\footnotetext{
${ }^{10}$ Warkum Sumitro, Asas-Asas Perbankan Islam dan Lembaga-Lembaga Terkait, Edisi Revisi, (JakartaL Raja Grafindo Persada, 1996), hal. 224

${ }^{11}$ H. Habib Nazir, et. all, Op. Cit., hal. 448

${ }^{12}$ Ibid, hal. 668

${ }^{13}$ Ibid, hal. 459

${ }^{14}$ Ibid, hal. 332

${ }^{15}$ Ibid, hal. 279

${ }^{16}$ Ibid, hal. 582

${ }^{17} \mathrm{Ibid}$, hal. 266
} 
Sedangkan pengertian rahn menurut syara' adalah menahan sesuatu dengan cara yang dibenarkan yang memungkinkan untuk ditarik kembali. Maksudnya adalah menahan barang yang mempunyai nilai harta menurut pandangan syara' yang dijadikan jaminan utang, kemudian sipembeli harta tersebut diperbolehkan mengambil utang seharga nilai barangnya atau sebagian. ${ }^{18}$

Selain kegiatan di atas, menurut Pasal 29 Surat Keputusan Direksi Bank Indonesia tersebut juga menyebutkan bahwa Bank dapat pula melakukan kegiatan antara lain :

a. melakukan kegiatan dalam valuta asing berdasarkan prinsip sharf,

b. melakukan kegiatan penyertaan modal berdasarkan prinsip musyarakah dan/atau mudharabah pada Bank atau perusahaan lain yang melakukan Kegiatan Usaha berdasarkan prinsip Syari'ah. ${ }^{19}$

Prinsif sharf adalah suatu akad jual beli mata uang (valuta) dengan mata uang lainnya. Sharf menurut definisi para ulama adalah memperjualbelikan uang dengan uang sejenis maupun yang tidak sejenis. ${ }^{20}$

Undang-Undang Nomor : 21 Tahun 2008 tentang Perbankan Syariah Pasal 19 ayat (1) menyebutkan :

(1) Kegiatan usaha Bank Umum Syariah meliputi:

a. menghimpun dana dalam bentuk Simpanan berupa Giro, tabungan atau bentuk lainnya yang dipersamakan dengan itu berdasarkan Akad wadi'ah atau Akad lain yang tidak bertentangan dengan Prinsip Syariah;

b. menghimpun dana dalam bentuk Investasi berupa Deposito, Tabungan, atau bentuk lainnya yang dipersamakan dengan itu berdasarkan Akad mudharabah atau Akad lain yang tidak bertentangan dengan Prinsip Syariah;

c. menyalurkan Pembiayaan bagi hasil berdasarkan Akad mudharabah, Akad musyarakah, atau Akad lain yang tidak bertentangan dengan Prinsip Syariah;

d. menyalurkan Pembiayaan berdasarkan Akad murabahah, Akad salam, Akad istishna', atau Akad lain yang tidak bertentangan dengan Prinsip Syariah;

e. menyalurkan Pembiayaan berdasarkan Akad qardh atau Akad lain yang tidak bertentangan dengan Prinsip Syariah;

f. menyalurkan Pembiayaan penyewaan barang bergerak atau tidak bergerak kepada Nasabah berdasarkan Akad ijarah dan/atau sewa beli dalam bentuk ijarahmuntahiya bittamlik atau Akad lain yang tidak bertentangan dengan Prinsip Syariah;

g. melakukan pengambilalihan utang berdasarkan Akad hawalah atau Akad lain yang tidak bertentangan dengan Prinsip Syariah;

h. melakukan usaha kartu debit dan/atau kartu pembiayaan berdasarkan Prinsip Syariah;

i. membeli, menjual, atau menjamin atas risiko sendiri surat berharga pihak

\footnotetext{
${ }^{18}$ Ibid, hal. 547

${ }^{19}$ Warkum Sumitro, Op. Cit., hala.225.

${ }^{20}$ H. Habib Nazir, et. all, Op. Cit., hal. 587
} 
ketiga yang diterbitkan atas dasar transaksi nyata berdasarkan Prinsip Syariah, antara lain, seperti Akad ijarah, musyarakah, mudharabah, murabahah, kafalah, atau hawalah;

j. membeli surat berharga berdasarkan Prinsip Syariah yang diterbitkan oleh pemerintah dan/atau Bank Indonesia;

k. menerima pembayaran dari tagihan atas surat berharga dan melakukan perhitungan dengan pihak ketiga atau antar pihak ketiga berdasarkan Prinsip Syariah;

1. melakukan Penitipan untuk kepentingan pihak lain berdasarkan suatu Akad yang berdasarkan Prinsip Syariah;

m. menyediakan tempat untuk menyimpan barang dan surat berharga berdasarkan Prinsip Syariah;

n. memindahkan uang, baik untuk kepentingan sendiri maupun untuk kepentingan Nasabah berdasarkan Prinsip Syariah;

o. melakukan fungsi sebagai Wali Amanat berdasarkan Akad wakalah;

p. memberikan fasilitas letter of credit atau bank garansi berdasarkan Prinsip Syariah; dan

q. melakukan kegiatan lain yang lazim dilakukan di bidang perbankan dan di bidang sosial sepanjang tidak bertentangan dengan Prinsip Syariah dan sesuai dengan ketentuan peraturan perundang-undangan

Dalam istilah perekonomian Islam, ijarah (disebut juga dengan leasing) dikenal dengan dua macam yaitu ijarah yang didasarkan atas periode/masa sewa. Kedua ijarah muntahiyyah bittamlik, dibeberapa Negara Islam menyebutnya dengan istilah ijarah wa iqtina yang berarti menyewa dan setelah itu diakui oleh penyewa. ${ }^{21}$

Selain itu berdasarkan Pasal 20 ayat (1) juga menyebutkan :

(1) Selain melakukan kegiatan usaha sebagaimana dimaksud dalam Pasal 19 ayat (1), Bank Umum Syariah dapat pula:

a. melakukan kegiatan valuta asing berdasarkan Prinsip Syariah;

b. melakukan kegiatan penyertaan modalpada Bank Umum Syariah atau lembaga keuangan yang melakukan kegiatan usaha berdasarkan Prinsip Syariah;

c. melakukan kegiatan penyertaan modal sementara untuk mengatasi akibat kegagalan Pembiayaan berdasarkan Prinsip Syariah, dengan syarat harus menarik kembali penyertaannya ;

d. bertindak sebagai pendiri dan pengurus dana pensiun berdasarkan Prinsip Syariah;

e. melakukan kegiatan dalam pasar modal sepanjang tidak bertentangan dengan Prinsip Syariah dan ketentuan peraturan perundang-undangan di bidang pasar modal;

f. menyelenggarakan kegiatan atau produk bank yang berdasarkan Prinsip Syariah dengan menggunakan sarana elektronik;

${ }^{21}$ Ibid, hal. 284 
g. menerbitkan, menawarkan, dan memperdagangkan surat berharga jangka pendek berdasarkan Prinsip Syariah, baik secara langsung maupun tidak langsung melalui pasar uang;

h. menerbitkan, menawarkan, dan memperdagangkan surat berharga jangka panjang berdasarkan Prinsip Syariah, baik secara langsung maupun tidak langsung melalui pasar modal; dan

i. menyediakan produk atau melakukan kegiatan usaha Bank Umum Syariah lainnya yang berdasarkan Prinsip Syariah.

Dalam setiap kegiatan menyalurkan dana pembiayaan kepada nasabah dilakukan dengan membuat suatu perjanjian yang isinya dan formulasinya selalu sudah ditentukan secara sepihak oleh pihak bank. Dalam setiap isi dan formulasi atau konstruksi perjanjian pembiayaan kepada bank, dicantumkan hak dan kewajiban masing-masing pihak, bank dan nasabah.

Berdasarkan ketentuan hukum Islam, perjanjian (aqad) memiliki rukun dan syarat serta asas-asas yang harus dipenuhi agar perjanjian tersebut menjadi sah, apabila rukun dan syarat serta asas-asas tidak terpenuhi maka perjanjian (aqad) tersebut menjadi batal (tidak sah).

Menurut Amin Summa bahwa asas-asas yang harus dipenuhi oleh sebuah perjanjian ( $a q a d)$ yang menganut prinsip syariah adalah Asas Ridha'iyah (rela sama rela), Asas Manfaat, Asas Keadilan, dan Asas Saling Menguntungkan. ${ }^{22}$

Dalam pelaksanaan perjanjian (aqad) pihak perbankan telah menyediakan perjanjian (aqad) jadi (standard contract), sehingga nasabah seringkali tidak berdaya untuk dapat menyampaikan inisiatif melakukan asas kebebasan untuk membuat perjanjian (aqad) sehingga masing-masing pihak dapat memenuhi hak dan kewajiban dan mendapatkan keadilan, oleh pihak bank yang terjadi hanya pembacaan isi perjanjian (aqad) yang disiapkan materai untuk ditanda tangani, keterpaksaan nasabah menerima beberapa klausula yang seharusnya tidak diinginkan oleh nasabah ada dalam perjanjian (aqad), tetapi karena kepentingan bisnis dan finansial yang mendesak, maka nasabah dengan terpaksa menerima perjanjian (aqad) jadi (standard contract) yang pada umumnya telah disediakan oleh pihak bank, baik itu perbankan konvensional maupun perbankan berbasis syari'ah.

Permasalahan tersebut di atas tentu saja akan berdampak kepada timbulnya pandangan negatif dari pihak-pihak yang kurang bahkan tidak menginginkan syari'ah (hukum Islam) dijalankan oleh umat Islam itu sendiri.

Untuk menjamin agar setiap bank yang mengklaim sebagai bank syariah, tetap berada pada jalur syariah dalam melaksanakan aktifitasnya, berdasarkan Surat Keputusan Direksi Bank Indonesia Nomor : 31/34/KEP/DIR tentang Bank Umum Berdasarkan Prinsip Syariah tanggal 12 Mei 1999 Pasal 19 ayat (2), bank dalam menjalankan kegiatannya akan diawasi oleh sebuah badan yang disebut dengan

${ }^{22}$ Amin Summa, Ekonomi Syariah Sebagai alternatif Sistem Ekonomi Konvensional, Jurnal Hukum Bisnis (Agustus 2002), hal. 16 
Dewan Pengawas Syari'ah (DPS) yang berkedudukan di Kantor Pusat, sehingga kegiatan bank tersebut tidak menyimpang dari prinsip syariah yang sebenarnya.

Penyimpangan dimaksud bukan hanya dalam penyaluran dan pemanfaatan dana oleh dan dari bank, juga tentang berbagai perjanjian (aqad) yang dibuat oleh bank dan nasabah. DPS harus memberikan pengawasan terhadap semua aktifitas bank syariah sehingga tidak menyimpang dari Syariah (Hukum Islam).

Selanjutnya Pasal 20 ayat (1) Surat Keputusan tersebut menyebutkan tentang fungsi Dewan Pengawas Syari'ah adalah mengawasi kegiatan atau usaha bank agar sesuai dengan prinsip Syariah. Dari Pasal tersebut maka kedudukan Dewan Pengawas Syari'ah sangatlah penting peranannya dalam mengawasi kegiatan atau usaha bank dari segi hukum Syariah.

Pelaksanaan perjanjian (aqad) yang dilakukan antara bank Syariah dengan nasabah maka penggunaan dana oleh nasabah perlu mendapatkan pengawasan dari pihak bank Syariah karena kegiatan usaha pembiayaan mudharabah dan musyarakah mempunyai potensi risiko yang relatif tinggi, sebagaimana disebutkan oleh Syafi'i Antonio, yaitu :

1. side streaming, nasabah menggunakan dana itu bukan seperti disebut dalam kontrak ;

2. lalai dan kesalahan yang disengaja;

3 . penyembunyian keuntungan oleh nasabah bila nasabahnya tidak jujur. ${ }^{23}$

Penyimpangan dari isi perjanjian (aqad) tentu saja menjadi sengketa antara bank dengan nasabah, hal ini telah diantisipasi oleh pihak bank, maka dalam setiap isi perjanjian selalu dicantumkan klausula yang menyebutkan bahwa jika antara bank dengan nasabah terjadi sengketa akan diselesaikan melalui Badan Arbitrase Mu'amalat Indonesia (BAMUI) yang dibentuk oleh Majelis Ulama Indonesia tanggal 21 Oktober 1993.

Di samping itu Undang-Undang Nomor 3 Tahun 2006 tentang Perubahan Undang-Undang Nomor 7 Tahun 1989 tentang Peradilan Agama, pada Pasal 49 telah menyebutkan bahwa Pengadilan Agama bertugas dan berwenang memeriksa, memutus, dan menyelesaikan perkara-perkara di tingkat pertama antara orang-orang yang beragama Islam di bidang :

a. Perkawinan;

b. Kewarisan;

c. Wasiat;

d. Hibah;

e. Wakaf;

f. Zakat;

g. Infaq;

h. Shadaqah dan

i. Ekonomi Syariah.

Dalam ketentuan Pasal 49 dijumpai ketentuan yang menyebutkan kata-kata "menyelesaikan perkara-perkara di tingkat pertama antara orang-orang yang

${ }^{23}$ Muhammad Syafi'i Antonio, Op. Cit., hal. 94 dan 98. 
beragama Islam”. Kemudian dalam penjelasan Pasal demi Pasal, Pasal 49 di atas disebutkan ruang lingkup atau cakupan yang termasuk dalam "antara orang-orang yang beragama Islam", yaitu "yang dimaksud dengan antara orang-orang yang beragama Islam" adalah termasuk orang atau badan hukum yang dengan sendirinya menundukkan diri dengan suka-rela kepada hukum Islam mengenai hal-hal yang menjadi kewenangan Peradilan Agama sesuai dengan ketentuan Pasal ini.

Bank Indonesia sebagai regulator perbankan di Indonesia telah mengeluarkan Peraturan Bank Indonesia Nomor 7/46/PBI/2005 menyebutkan bahwa dalam perjanjian antara bank Syariah dengan nasabah harus mencantumkan klausula penyelesaian sengketa dalam perbankan syariah melalui musyawarah dan Badan Arbitrase Syariah Nasional. Peraturan tersebut tentu saja sangat bertentangan dengan asas hukum yang berlaku di Indonesia.

Kemudian pada tahun 2007 Bank Indonesia kembali mengeluarkan Peraturan Bank Indonesia Nomor 9/19/PBI/2007 tentang Pelaksanaan Prinsip Syariah Dalam Kegiatan Penghimpunan Dana dan Penyaluran Dana Serta Pelayanan Jasa Bank Syariah. Pasal 8 menyebutkan bahwa sejak berlakunya Peraturan Bank Indonesia Nomor 9/19/PBI/2007 tentang Pelaksanaan Prinsip Syariah Dalam Kegiatan Penghimpunan Dana dan Penyaluran Dana Serta Pelayanan Jasa Bank Syariah, maka Peraturan Bank Indonesia Nomor 7/46/PBI/2005 dinyatakan tidak berlaku lagi, sehingga sengketa dalam perbankan syariah yang muncul akibat perjanjian yang terjadi sejak tanggal 17 Desember 2007 dapat diselesaikan melalui lembaga arbitrase atau lembaga peradilan apabila dalam akta perjanjian yang dibuat para pihak di dalamnya tidak terdapat klausula arbitrase.

Ketentuan tersebut tentu saja sangat berbeda dengan ketentuan yang terdapat dalam Pasal 55 ayat (1) Undang-Undang Nomor 21 Tahun 2008 tentang Perbankan Syariah yang dengan tegas menyatakan bahwa sengketa dalam Perbankan Syariah adalah kewenangan Peradilan Agama, meskipun dalam ayat (2) tetap dibuka peluang penyelesaian selain dalam lembaga Peradilan Agama. Dengan demikian bahwa sejak berlakunya Undang-Undang Nomor 21 Tahun 2008 tentang Perbankan Syariah maka penyelesaian sengketa perbankan Syariah adalah menjadi kewenangan Peradilan Agama sepanjang tidak ada klausula dalam akadnya akan diselesaikan melalui lembaga lain.

Bank Muamalat Indonesia adalah bank pertama dan terdepan dalam menjalankan aktifitasnya berdasarkan prinsip-prinsip Syariah yang tentu saja dalam membuat perjanjian (aqad) masih menggunakan perjanjian (aqad) jadi (standar contract), namun rukun, syarat, dan asas-asas perjanjian (aqad) sesuai syariah (Hukum Islam) adalah sesuatu yang muklat terpenuhi, maka DPS juga harus berperan aktif dalam menjalankan pengawasannya dan penyelesaiannya harus dilaksanakan.

\section{PENUTUP}

Pengaturan Akad Musyarakah yang dilaksanakan di Bank Muamalat Indonesia Cabang Banyuwangi, ditinjau dari segi hukum Islam dan peraturan perundang-undangan perbankan Syariah sudah memenuhi syarat-syarat sahnya 
akad, telah berpedoman kepada al-Qur'an, hadits, Ijma' dan qiyas serta Fatwa Dewan Syari'ah Nasional Majelis Ulama Indonesia Nomor : 7/DSN/MUI/IV/2000, tentang pembiayaan Musyarakah sebagaimana telah diterangkan dasar hukum, dan apabila realisasinya tidak sesuai dengan fatwa Dewan Syari'ah Nasional, maka Dewan pengawas Syari'ah sebagai perpanjangan tangan dari Dewan Syari'ah Nasional akan melakukan teguran. Terhadap pelaksanaan akad ini memang terjadi perkembangan yang sangat kontemporer dari asli pelaksanaan yang dilankan pada jaman Nabi dan umat sesudahnya. Modal kepercayaan saja masih sangat mendominasi, tetapi untuk kondisi sekarang yang sebagaimana dikelola oleh bank syari'ah tidak cukup dengan modal kepercayaan kepada debitur/nasabah, sehingga diperlukan pula jaminan dalam pembiyaan musyarakah tersebut.

\section{DAFTAR PUSTAKA}

\section{Buku}

Abul A'la Al-Maududi \& Fazl Ahmed, Pedoman Perkawinan dalam Islam, Dilengkapi dengan Studi Kasus tentang Hukum Perkawinan dan Perceraian, (Terjemahan Alwijah), Darul Ulum Press, Jakarta, 1987.

Mustofa dan Abdul Wahid, Hukum Islam Kontemporer, Sinar Grafika, Jakarta, 2008.

Bambang Sunggono, Metodologi Penelitian Hukum, Raja Grafindo Persada, jakarta, 1997.

Johannes Ibrahim dan Lindawati Sewu, Hukum Bisnis dalam Persepsi Manusia Modern, Refika Aditama, Bandung, 2004

Kompilasi Hukum Islam.

Mohammad Daud Ali, Hukum Islam, Ilmu Hukum dan Tata Hukum Islam di Indonesia, Pustaka Rajagrafindo Persada, Jakarta, 1998.

Muhammad Luqman hakiem, Deklarasi Islamtentang Hak Asasi manusia, Risalah Gusti, Surabaya, 1993.

M. Quraish Shihab, Membumikan Al-Qur'an, Fungsi dan Peran Wahyu dalam Kehidupan Masyarakat, Mizan, Bandung, 1992

Nurcholish Madjid, Masyarakat Religius, Yayasan Paramadina, Jakarta, 1997.

Soemiyati, Hukum Perkawinan Islam dan Undang-undang Perkawinan (UndangUndang Nomor 1 Tahun 1974 tentang Perkawinan, Liberty, Yogyakarta, 1986.

Soerjono Soekanto dan Sri Mamudji, Penelitian Hukum Normatif, Suatu Tinjauan Singkat, Pustaka raja Grafindo, Jakarta, 1995.

Sulaiman Rasyid, Fiqh Islam, At-Tahiriyah, Jakarta, 1976. 
UU Nomor 1 Tahun 1974 tentang Perkawinan

UU Nomor 39 Tahun 1999 tentang Hak Asasi Manusia.

Internet

http://syamsuri149.wordpress.com/2008/02/06/membangun-keluarga-sakinah/, diakses tanggal 3 Desember 2011.

http://lathifa98.blogspot.com/2010/01/hak-perempuan-dalam-memilih-jodoh.html, diakses tanggal 5 Desember 2011)

http://rikirikiapriadi.blogspot.com/2011/03/pengertian-sejarah-ham.html, diakses Tanggal 16 Desember 2011 